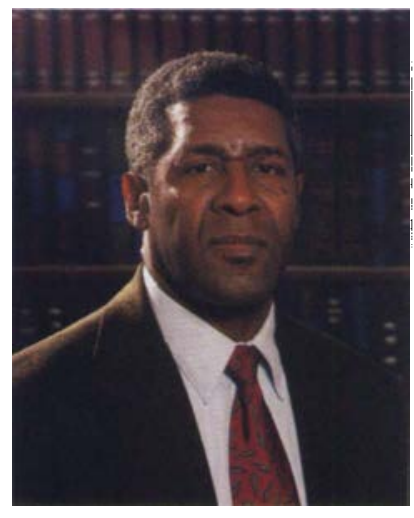

\title{
Small farms re-emerge in national agenda
}

\author{
DESMOND A. JOLLY
}

Director

UC Statewide Small Farm Program

In recent decades, policy-makers have often measured the value of farms in terms of their production economics. Society was seen as better off if larger, more efficient farms displaced smaller, less efficient ones. Such analysis drove much public policy and research effort, and informed allocations of technical and government assistance.

In contrast, the USDA National Commission on Small Farms called for diversity in farm operations in its 1998 report A Time to Act. The Commission noted that $60 \%$ of all farms are less than 180 acres. The responsible management of the soil, water and wildlife encompassed by these operations are of significant public benefit. In many rural communities, small-scale family farms provide an economic foundation, generating revenues, taxes and jobs for local communities. Consumers connect with agriculture more readily through the direct-marketing efforts associated with smaller operations than through the packer, shipper and supermarket.

The Commission noted, "Landowners who rely on local business and services for their needs are more likely to have a stake in the well-being of the community. In turn, local landowners are more likely to be held accountable for any negative actions that harm the community."

This perception of small-scale farming as more conducive to a sustainable democracy and to sustainable communities was a foundation principle of Thomas Jefferson's democratic vision. In Jefferson's view, "Cultivators of the earth are the most valuable citizens. They are the most vigorous, the most independent, the most virtuous, and they are tied to their country, and wedded to its liberty and interests, by the most lasting bonds."

The Jeffersonian vision guided the development and adoption of agricultural policies from 1860 for another hundred years. The Homestead Act of 1862, the Morrill Land Grant Act of 1862, the Hatch Experiment Station Act of 1867, the Morrill Land Grant Act of 1890, the Smith-Lever Act of 1914 and a host of other public policies were all embodiments of this concept.

The Depression of the 1930s stimulated an exodus of people from family farms, and the strong industrial expansion caused by war production and the Cold War created a pull towards the cities, to manufacturing and service industries. Intensification of agricultural technology in the form of mechanization, petrochemicals and improved plant varieties created excess capacity in agriculture putting further pressure on the sustainability of small-scale farming.
By the 1970s, however, diminishing diversity in U.S. agriculture began to reawaken interest in small-scale, family farming. In California, public concerns led to production of a seminal report - The Family Farm in California: Report of the Small Farm Viability Project submitted to the State of California in November 1977. Specifically, it recommended more targeted involvement of the University in providing "technical assistance and information to assist small producers in modifying their operations...."

In response, UC's Division of Agriculture and Natural Resources established the Small Farm Program in 1979 and the Center for Cooperatives in 1987.

A parallel concern about family-scale farms was articulated at the national level. In January 1981 the USDA published $A$ Time To Choose - Summary Report on the Structure of Agriculture. In his foreword, Secretary of Agriculture Bob Bergland described the prevailing philosophy of postwar federal policies: "We thought - we hoped - that if we helped the major commercial farmers, who provided most of the food and fiber (and exerted most of the political pressure), the benefits would filter down to the intermediate-sized and then the smallest producers." This "one size fits all" scale-neutral paradigm is generally giving way to the more realistic notion that research needs and educational approaches, as well as risk management strategies, may vary with scale.

For the first time, this past year USDA specified small farms as among the criteria for allocating research and education grants in its Requests for Proposals for the NRI and its Food Safety Initiative grants. The UC Small Farm Center successfully competed for a $\$ 180,000$ grant under the Food Safety Initiative.

There is also burgeoning public interest in small farms. The recent 2nd National Small Farm Conference held in St. Louis, Mo., drew more than 700 participants - mainly professionals from land-grant universities, Cooperative Extension, USDA and nonprofit organizations. In November, California's 1999 Farm Conference in Berkeley drew more than 500 participants.

This expression of interest comports well with increasing recognition of the worth of rural people and rural places, diverse ownership of the assets that create wealth, and careful stewardship of natural resources. These values should guide the land-grant university system as it shapes its research, education and extension agenda. Now is the time to support the rich diversity of agricultural operations that have been so important to California agriculture and the nation. 